DOI: https://doi.org/10.24195/2414-4665-2017-5-13

UDC: $37.091 .33: 811.11$

\begin{abstract}
Inna Shymkiv,
PhD (Candidate of Pedagogical Sciences), associate professor, Department of German Philology and the German Language Teaching,
\end{abstract}

Anatolii Klymenko,

PhD (Candidate of Pedagogical Sciences), associate professor, Department of Practical English and Language Teaching,

Nataliia Zakordonets,

PhD (Candidate of Pedagogical Sciences), associate professor,

Department of Foreign Languages,

Ternopil Volodymyr Hnatiuk National Pedagogical University,

2, M. Kryvonosa Str., Ternopil, Ukraine

\title{
IMPLEMENTATION OF ALTERNATIVE METHODS OF FOREIGN LANGUAGES TEACHING IN THE CONTEXT OF COMPETENCY-BASED APPROACH
}

\begin{abstract}
Methodology of foreign languages teaching (FLT) has been continually undergoing changes with the attempt to find the most appropriate approach or approaches satisfying a contemporary need for learning. A new stage in the development of foreign language education is associated primarily with the implementation of a qualified approach into the educational process. Its idea is to form an innovative personality who can flexibly adapt to global, socio-political and economic factors. The issue of competency-based learning (CBL) is being investigated by a number of scholars but its certain aspects still remain understudied. The paper aims to highlight the major approaches of alternative methods of teaching foreign languages in the framework of CBL methodology. The following research methods were used in the study: critical analysis of scientific literature, general scientific methods of analysis, synthesis, comparison, generalization, as well as the empirical ones, such as observation, testing, generalization of experience of lecturers, pedagogical experiment. Special attention in the paper is paid to understanding the productive trends of teaching foreign languages in the context of student-centered and activity-oriented technologies which are primarily associated with alternative (non-traditional) methods in the context of CBL. CBL of foreign languages gives students an opportunity to explore issues, observe, analyze, think critically, and choose their own methods of learning. The results of the carried out experiment show that the efficacy of competency-based approach in teaching foreign languages depends on teacher's understanding of the necessity to abandon authoritarian and scholastic methods, and use alternative and innovative ones instead.
\end{abstract}

Keywords: alternative methods of teaching, competency-based approach, student-centered learning, activityoriented technologies, assessment, motivation, self-assessment, educational consultation.

\section{Introduction}

Under the conditions of transformation processes of global dimension (i.e., globalization, cultural diffusion, demographic crisis, migratory wave of innovation in science and technology, strengthening transnational interdependence, speed and frequency of communication in various fields) education is considered to be a crucial factor of social improvement, sustainable development and competitiveness of countries in the global labor market and services. New trends in defining the role and the peculiarities of the development of foreign language education are of global and philosophical nature. Language education is an important tool which forms the ability of an individual to quickly adapt to a multicultural and multilingual community of people. It is the way to be mobile in the society that is constantly changing. Communication, in its broad sense, empowers people to hold a dialogue of cultures in the globalized world helping to solve important problems.

Methodology of teaching foreign languages has been continually undergoing changes with the attempt to find the most appropriate approach that would satisfy a contemporary need for learning. A new stage in the develop- ment of foreign language teaching is associated primarily with the introduction of a qualified approach to the educational process. Its idea is to shape an innovative personality who can flexibly adapt to global, socio-political and economic factors. It is the Competency-Based Learning (CBL) that is a powerful combination of "education for all" with "education for everyone" (Savchenko, 2011).

For the acquisition of key competences throughout life students should get more autonomy in training with an opportunity to hold responsibility for their own learning environment and create conditions for self-realization and self-development. The core competencies include knowledge, skills and life experience of an individual and presuppose the ability to communicate in foreign languages; mathematical competence and basic competences in science and technology; digital computer competence; ability to learn throughout life in professional and social contexts; social and civic competence; the competence of being initiative and entrepreneurial as well as the competence of education and cultural expression. In the context of CBL, teachers must constantly update their professional skills and develop new approaches taking into account 
the fact that there are students with diverse learning needs and capabilities in the classroom.

We are convinced that a traditional paradigm of foreign language training "teacher - student" under modern conditions should be transformed into a different one like "student - information / textbook - teacher". That is why our attention is focused on understanding the productive trends of teaching foreign languages in the context of student-centered and activity-oriented technologies which are primarily associated with alternative (non-traditional) methods in the context of CBL. CBL of foreign languages gives students an opportunity to explore issues, observe, analyze, think critically, and choose their own methods of learning. They also learn how to ground their opinions, develop the ability to assess risks and form constructive management of feelings. The CBL techniques encourage students to use information and communication technologies, to interact in an adequate and creative way in all kinds of social and cultural contexts. By doing this, they enrich their experience, apply fundamental knowledge and skills in practice, as well as use self-assessment and constructive feedback.

There is a number of scholars involved in studying various aspects of CBL in the educational process. This makes the issue both topical and richly varied. Thus, S. Bondar (Bondar, 2012) and I. Rodyhina (Rodyhina, 2008) deal mainly with competency-oriented content and structure of school subjects in the context of fundamental education. O. Lokshyna (Lokshyna, 2009) studies competency-oriented framework of school education development in the EU countries. O. Savchenko (Savchenko, 2011) deals with the issue of competency-oriented curriculum for young learners. S. Trubacheva (Trubacheva, 2004) dwells on the conditions of implementing competency-oriented approach into the educational process. Some aspects of the issue of competency-based training in the framework of teaching and learning foreign languages have been discussed in the works of S. Ballweg, K.R. Bausch, H. Christ, H.-J. Krumm (Bausch, Christ \& Krumm, 1995; Ballweg, 2013) (research on the issue of foreign languages learning), B. Kolomiyets, S. Soshenko (Kolomiyets \& Soshenko, 2014) (the development of the methods of teaching foreign languages), W. Mattes, B. Hugenschmidt, A. Technau (Mattes, 2012; Hugenschmidt \& Technau, 2011) (the peculiarities of implementing activity-oriented methods into the process of teaching foreign languages), etc. Claire Kramsch (Claire Kramsch, 2014) has analyzed the historical and subjective dimension of language-as-culture and the ways it impacts the teaching and learning of foreign languages. Handoyo Puji Widodo, Avilanofa Bagus Budi and Fitri Wijayanti (Widodo, Budi \& Wijayanti, 2016) examined the extent to which Poetry Writing 2.0 could create an expressive and creative English language learning environment. Ulf Schuetze and Erin Lowey (Schuetye \& Lowey, 2015) carried out the study with intermediate learners of German and native speakers of German who participated in an online exchange testing the functionali- ty of a toolbar while providing a variety of tasks and feedback to the learner in an online exchange setting.

However, despite the recent developments, the issue of choosing the most effective teaching methods remains open for revision, improvement and discussion. That is why the choice of our topic has been made with special focus on the features of alternative (non-traditional) methods of teaching foreign languages within CBL methodology.

Taking the above mentioned into consideration the relevance and significance of the issue can be explained by the following aspects:

- socio-economic requirements of finding the most appropriate rational approaches to foreign language teaching in terms of new challenges for time and society (globalization, cultural diffusion, migration waves, the speed and frequency of communication in various spheres);

- necessity for the development, accomplishment and implementation of efficient methods of foreign language teaching into the educational process, that would facilitate reorientation of teacher performance from formal indicators of internal control to the needs of individual learners; shifting from education as "knowledge transfer" to the productive learning when the knowledge acquisition occurs through the process of creation of students' original learning achievement.

The article aims to highlight the major approaches of alternative methods of teaching foreign languages in the framework of CBL methodology.

According to the objective of this paper we provide the solution for the following fundamental tasks:

1) outline the basic levels of FLT in the context of learner-centered and pragmatist measurement.

2) analyze the main strategies and forms of FLT in the context of productive learning;

3) study the key advantages of alternative methods of FLT in comparison with the traditional teaching methods;

4) provide the examples of exercises for competence-oriented approach to FLT;

5) suggest practical recommendations on the use of alternative methods of FLT in teaching and learning process.

\section{Research methods}

In accordance with the specificity of the issue examined and tasks assigned, the following research methods were used: critical analysis of scientific literature, general scientific methods of analysis, synthesis, comparison, generalization; as well as empirical methods (observation, testing, pedagogical experiment).

\section{Discussion}

Competency in foreign languages requires knowledge of vocabulary and functional grammar as well as awareness of the main types of verbal interaction and language registers. What is also important is the knowledge of social conventions and cultural aspects and the variability of the language. Competency-based approach to teaching foreign languages involves chiefly 
reorientation from the process into the result in the context of student-centered and activity-oriented dimensions (Ballweg, 2013). Hence, the four basic levels of language training can be differentiated:

1) content-subject learning is aimed at acquiring and mastering basic cognitive and practical skills and abilities needed to solve problems by applying appropriate methods, materials and information; forming digital computer competency which involves using computers for doing a search on information, its integrated analysis, production, presentation and exchange; forming interdisciplinary connections; communicating in foreign languages; individual expression through cultural education; civic competence; motivation and willingness of an individual to continue lifelong learning;

2) systemic learning creates the capacity for independent development of new knowledge and integration of knowledge from different fields, application of life experience, declarative knowledge and skills; flexible processing of complex messages in the context of the completeness and accuracy of understanding specific information, drawing conclusions or independent assessment of the conclusions proposed pursuant to a situation; the ability to think logically, to put forward arguments, to develop one's own intellectual position, to predict the semantic level, to apply the necessary material adequately using the mass media; to be open to acquiring new knowledge and adapting to changes; ability to work in a team; ability to present oneself and to assess one's work critically; willingness to design educational strategies; ability to organize and apply learning tools for selfeducation;

3) communicative learning is focused on implementing different types of speech activity, namely perception, production, interaction or mediation; the ability to teach the formation of opinion in terms of its lexical, grammatical and stylistic design; possession of skills needed for various kinds of reading (reading for the gist, close reading, skimming, scanning, etc.). Communicative approach presupposes the ability to listen and hold a reasoned debate, to show flexibility in speech while sharing ideas and using a variety of language means to transfer denotative and connotative meanings. This type of learning is all about selection, differentiation and elimination of ambiguity; the ability to create complete and coherent statements using the full variety of appropriate structures and a wide range of connectors and other means of communication for giving clear, detailed descriptions and systematic presentation of the relevant allocation of key provisions and relevant ancillary parts; comply with the rules of conversation;

4) social learning enables effective and constructive participation of an individual in the socially-varied and complex societies; promotes understanding of typically accepted behaviors and manners, knowledge of basic concepts about individuals, groups, organizations, social class, gender equality and non-discrimination, showcases of tolerance and mutual understanding, understanding different points of view, the ability to empathize, overcome stress, resolve conflict situations and live in a heterogeneous society.

To keep to the aforementioned major levels of learning, it is necessary to consider a lot of different approaches to language learning (Ballweg, 2013, p. 97). Here are the main strategies of language learning in the context of productive learning:

- cognitive strategies are focused on developing memory skills and understanding specific information: creation of word clusters; visual semantics of lexical material with the help of drawings, pictures, cards, objects, etc.; implementation of verbal visualization (context) for better perception of lexical units; the identifying of logical connections between the elements of a message, differentiation between the main and additional information keeping in mind the most important one; comparison of text information with that of an object, picture, diagram, etc.; prediction on the level of context; making notes of the necessary information; the summarizing of the conclusions based on the content; noting the key words; visualization of connections (e.g., in a form of diagrams and drawings); the setting of systemic connections through analyzing examples; comparison of sounds, lexical units and grammatical structures in different languages; the using of grammatical structures in an active language system; application of audiovisual materials and/or application of computerized connections (using the Internet, watching films, etc.);

- metacognitive strategies are aimed at planning and performing educational activities: outlining educational goals and objectives; choosing working and social forms, working stations (classroom, library, etc.); setting time frameworks according to the level of task complexity and a set of some rules, effective time and information management; performing specific roles of "an actor", "a teacher" in the educational process instead of being "a passive observer", concentrating attention, creating an educational setting that would minimize or better eliminate distractions in the process of studying; assessing and self-assessing the level of academic achievements;

- affective strategies govern the learning process, such as overcoming students' exam and workload anxiety: promoting positive reinforcement training and readiness of students to succeed; developing individual learning style; overcoming barriers in the emotionally intense atmosphere of mutual understanding and respect;

- communicative strategies are aimed at establishing contacts and willingness to take the initiative in the process of direct dialogue: strengthening declarative knowledge and life experience, identifying the logical connections between the elements, the hypotheses nomination, putting into effect the interaction, choosing and using intonation and non-verbal means, using synonyms and paraphrase with the aim of grammatical and lexical planning, restructuring and correcting speech when faced with difficulty, using successive arguments, citing evidence for and against a particular point of view, the im- 
plementation of feedback on the allegations and findings, using different modification schemes.

The advantage of non-traditional teaching methods is the fact that they reject class-task system and evaluation of progress based on defined norms. Another advantage is a flexible, open learning space; variable composition of study groups; a free choice that students make according to the types and methods of learning activities; effective time and information management; self-learning, selfdiscipline and self-control; the willingness of an individual to overcome obstacles and adapt to changes. Such training methods contribute, in our opinion, to the formation of positive motivation of students who wish to apply their new knowledge in different life contexts.

Having performed a comparative analysis of traditional and alternative (non-traditional) approaches to teaching in general, and the system of evaluation in particular, we suggest to consider the following advantages of alternative teaching methods:

1) the peculiarities of learning: the idea of a differentiated approach in learning; reliance on independent development of cognitive abilities of students through stimulating the search process and inventive activity; maximum disclosure of internal capacity; creating favorable conditions for the development of activity, motivation and willingness to continue their studies and succeed in life; safe and attractive learning environment based on mutual respect and cooperation; conceptual use of reasonable methods of training; students' choice of work and social forms of teaching methods; timely response of a teacher as an observer, a teacher as a teacher, a teacher as a counselor, a teacher as a consultant to meet various educational needs of students in order to provide high quality advice, warnings and errors in overcoming educational barriers; common choice (student + teacher) of a better version of cognitive activity; formation mechanisms of self-prediction, self-development, and selfidentity. In this context, the traditional teaching methods, on the contrary, involve considering a teacher as a judge and as a controller; limitations in the choice of learning environment, forms and methods of training; the lack of freedom in selecting partners for communication among students; the lack of students' motivation; rigid structuring of educational material. Within the traditional framework students simply reproduce ready available language units at various levels, thematically organized material that does not contribute to the development of their creative abilities.

2) The peculiarities of evaluation: systematic active interaction of teachers and students in the evaluation process; using various evaluation technologies to collect information (letters of observation, sheets of assessment, "portfolio", various tests, evaluation of class and home work, presentations, etc.); assessing students' performance in an individual format; taking into account not only students' learning outcomes, but also how much effort they put into getting those results; the ability to track students' progress; active involvement of students in the evaluation process; students have the opportunity to independently evaluate their own work and demonstrate their personal achievements, comparing to their previous work, but not the work of other students; evaluation format that presupposes the problem solution. Traditional or conventional methods of evaluation, however, include one-way process of diagnosis which is regarded as an action performed by one person - a teacher as a controller; the lack of cooperative approach; evaluation of the final result is carried out to demonstrate the errors and failures; denial of the role of students in the evaluation process; limitations in the choice of assessment (for example, using only the final test); mechanical, standardized assessment of students' achievements.

Activity-oriented foreign language learning plays an important role in the formation of communication and lexical aspects of active basic grammatical. In accordance with the principle of communicative training and practical purpose - teaching foreign language communication - an activity-based approach involves forming abilities to express communicative intentions for mutual understanding among people. In this context, the implementation of activity-oriented communicative approach to foreign language teaching is carried out under the following conditions: learning situations should be constructed so that the learners have an opportunity to find their own solutions to problems; communicative speech situation should be based on unmodified, unabridged, authentic materials to encourage students to conduct discussions and focus on the communicative success. The topics of foreign language communication must reflect various aspects of students' life; promote their values and beliefs; students must be able to operate grammatical and lexical skills of speech in real communication situations and transfer speech actions and speech exercises into their speech habits (e.g. everyday situations in a restaurant when they need to order something, in an unfamiliar city they have to be able to navigate, to discuss various topics and adequately respond to actions of resolving any communication problems, to direct the content of communications to quickly find relevant information online, etc.) (Ende, 2013, p. 28).

In the framework of the learning process aimed at solving particular problems with necessary attributes of self-responsibility, self-evaluation and intensification of collaborative efforts of a student and a teacher, we suggest a three-phased educational process:

1) Introductory stage / Motivation: discussing home assignments; revision; identifying educational objectives; planning personal strategies for achieving the goals according to one's own characteristics and abilities; understanding one's own strong and weak points from the perspective of a learner; awareness of the task objectives; discussing transparent and understandable to students evaluation criteria; the formation of working groups and the establishment of relations between the parties; coordinating the roles ("an actor", "an observer", "a student as a teacher" and others) in the implementation of activities; 
range of social and working forms (individual work, group work, plenum, etc.); activation of previously acquired knowledge; "brainstorming"; development of affective factors (self-esteem, openness, engagement, motivation, encouragement).

2) Working stage / Learning the material: presentation of educational material; explanation / advice / teacher counseling; answering questions; elaboration of training material through the prism of an active cognitive process; identifying and resolving (individually or in a group) current educational issues; design work; conducting discussions; search for necessary information in databases, hypertext, etc., applying the processes of monitoring, analyzing, synthesizing, organizing and storing material in a particular educational situation; studying semantic fields and creating semantic maps; selection and systematization of grammatical structures, processes and relations; usage of educational support; information exchange; presentation of working results.

3) Summary stage / Assessment / Self-assessment: application of acquired knowledge in practice; transfer; reflection (form and content of training); summing up; reviewing the workflow; predicting the dynamics of success and the consequences of educational decisions; determining the degree of an individual's progress compared with his/her previous achievements; assessment (with the teacher and other students) and self-assessment: control tasks, observation sheets, portfolio, rating specific tasks according to the grid of selected categories (conversation, discussion, information exchange and others).

Activity-oriented teaching methods encourage learners to actively search for different ways of solving educational problems by disclosing their creative potential. Years of experience in teaching foreign languages let us state that there are certain educational activities as well as techniques and methods that help to promote the educational process, for example, "The Associations Star", "Aspect-Word-Outcome", "Fishbowl", "Sandwich Method", "Station work", "Domino Method", etc.

These methods can be easily used individually and within small and/or large groups of students. Here are a few examples of the aforementioned methods and techniques used in the classrooms of teaching foreign languages (German and English).

Example 1. "The Associations Star" suggests students to randomly add as many words as there are star rays. Students name the words as they conjure up in their minds. These are the examples of some associations (e.g. to the question "What are the things children can be afraid of?" a student/students think of short responses/words they get from their own or their friends' experience: loneliness, strict rules, parents' divorce, darkness, some animals and others). In this way communicative tasks in a form of questions in the framework of etiquette situations, social contact situations, social behavior situations, etc. can be used. We distinguish the following features of "The Associations Star" method:

1. Method application: studying a new topic; systematization and structuring the lexical material for the chosen topic.

2. Educational objectives: the development of spontaneous ideas and associative thinking, the ability to quickly respond to the statements of others; the ability to express one's point of view in a particular situation.

3. Performance / method usage: 1) the election of the speaker who reads out the task for the group, decides on the procedure and sums up the work, and the secretary who keeps records of the group work; 2) the speaker explains the procedure of the task in the group: a problem or questions should be clearly formulated and written on the classroom blackboard at the center of "associative stars" (circle, oval, etc.) to make them all clear and explicit; project participants should clearly and loudly express their views; each of the project participants has the opportunity to express his/her views repeatedly; reverse questions, critical comments made on the statements of other participants in the process of recording results are not provided.

4. Duration: $15-20$ minutes

5. Materials required: a situation, a problem, or an issue that has been prepared by a teacher or students in advance. They should be written on the blackboard in the pattern of a star with many rays.

6. Possible challenges in implementing the method/ ways of avoiding challenges: 1) the secretary while putting down all the words on the blackboard might feel overloaded and short of time to write all the project participants' remarks especially if they are randomly shouted out in a messy order. The way to prevent the problem is to appoint a facilitator who would make sure everyone keeps to the procedure of the task and provides words in a proper order; 2) students with better language skills and those who are usually more active and leaders of the class tend to be more initiative and will provide more responses than the students who are calm and not very ambitious. The way to prevent the problem is to make certain that every student in the classroom provides answers in turns. This should be a responsibility of a project secretary or facilitator. 


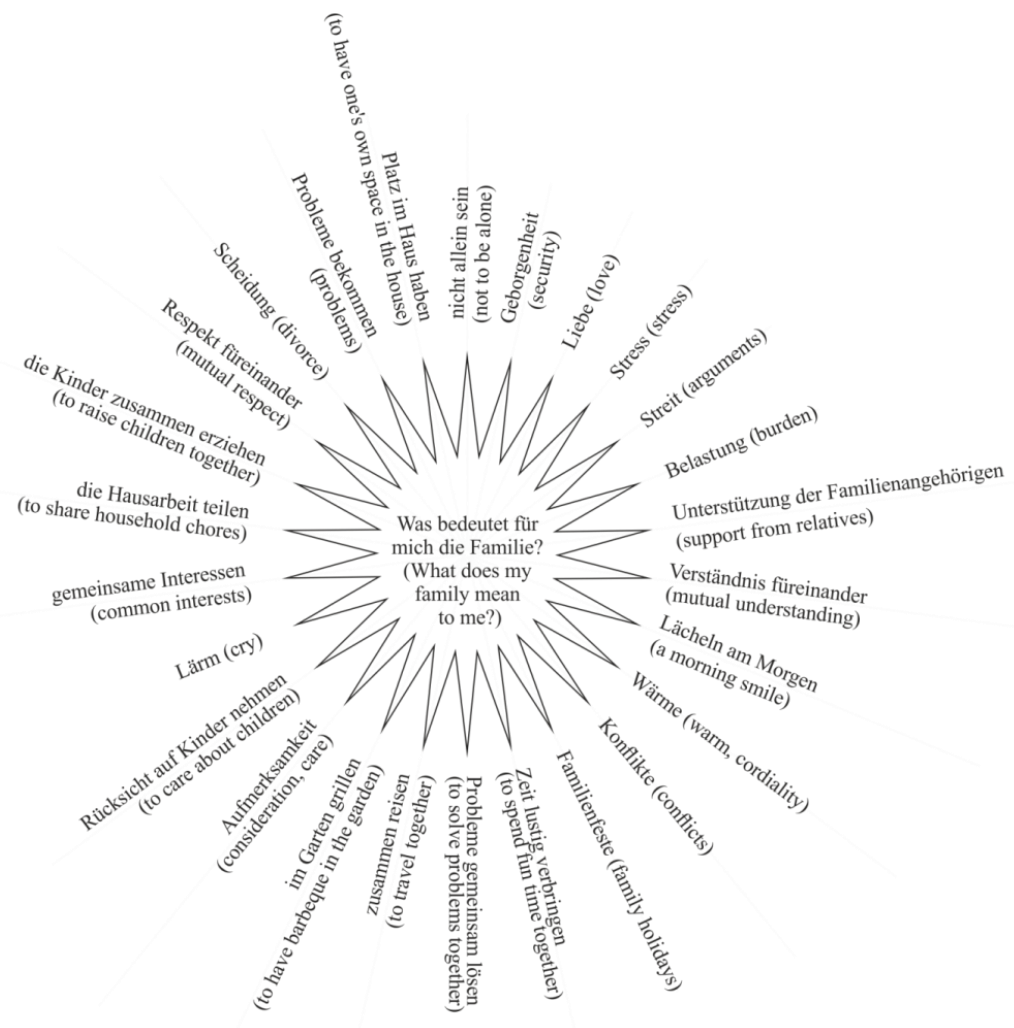

Fig.1. Example of "The Associations Star"

"The Associations Star" can be used in the following way. This is an example of the technique used for studying the topic "Familie" ("Family") in the process of learning the German language:

The tasks on the basis of the method of associations for the topic "Familie"( "Family") (through the example of learning German):

1. In small groups students are assigned the task to have a discussion based on the star rays associations that are written on the blackboard "Was ist für mich in der Familie besonders wichtig und warum?" (What is important for me in my family and why?). Every student should have a chance to speak in order to voice his/her opinion, participate in discussion, and systematize all pros and cons.

2. Each student prepares some questions for the discussion (the topic "Familie" ("Family")). For instance: "Warum ist die Familie Stress für mich?" (Why is my family stressful for me sometimes?), "Was braucht eine Familie zum Glücklichsein?" (What does family need to live happily?), "Was gehört zu einer "normalen" Familie?" (What does the notion "normal family" imply?), "Wann geht es Kindern in der Familie gut?" (When do the children in the family feel good?), "Was sind Frauensachen - was sind Männersachen in der Familie?" (What are typically female and male household chores in the family set-up?), "Sind Kinder Karrierekiller?" (Do children prevent parents from their career prospects?), "Konnte die Frau die Familie und Karriere erfolgreich vereinba- ren?" (Is it possible for a woman to successfully combine family life with professional commitments?), "Was ist ein richtiger Mann in der Familie?" (What is the role of a real man in the family?), "Was ist eine richtige Frau in der Familie?" (What is the image of a real woman in the family?), etc.

Example 2. The idea of the Method "Aspect-WordOutcome" is to suggest some words that begin with the same letter of the alphabet within a certain topic. For instance, for the topic "Food" students choose the general categories, such as "Fruits", "Pastry", "Beverages", "Vegetables", "Meat dishes" and decide on words that begin with the same letter. Let us briefly outline the general idea of implementing the method:

1. Method application: studying a new topic; systematization of acquired knowledge, assessment of what has been learnt.

2. Educational objectives: the development of associative thinking; the usage and implementation of the lexical units that have been studied.

3. Performance / method usage: 1) explanation of the method idea (by a teacher or the student who works as a speaker), 2) selection of topics and aspects of the topics suggested, 3) writing a topic and its aspects, 4) a teacher or the student who performs as a speaker pronounces a letter of the alphabet loudly and clearly (A), and then proceeds with naming the letters in his/her head until other students stop him/her any time. The letter that has been "caught" is voiced in the classroom; 5) all the stu- 
dents try to put down as many words as possible; 6) the one who finishes first says "Stop" and the work is done; all the papers are submitted for assessment, 7) if necessary, the task can be repeated (5-10 times).

4. Duration: 10-15 minutes.

5. Materials required: a piece of paper that has been prepared in advance; pens / pencils.

6. Possible challenges in implementing the method/ ways of avoiding the challenges: quick-thinking and ambitious students can be more proactive and initiative than those who are quiet and less talented for language learning. Thus, the first ones can discourage the others. The way to prevent the problem is to divide a group into mixed types of students working together. That would provide equal opportunities for both parties in the process of task achievement.

Here is an example of the method "aspect-wordoutcome" being used under the topic "Das Essen" ("Food") (German):

Example of "Aspect-Word-Outcome" method in use

\begin{tabular}{|l|l|l|l|l|}
\hline \multicolumn{5}{|c|}{ Das Essen (Food) } \\
\hline $\begin{array}{l}\text { Obstsorte (kinds of } \\
\text { fruits) }\end{array}$ & $\begin{array}{l}\text { Gebäckart (types of } \\
\text { pastry) }\end{array}$ & Getränk (drinks) & Gemüse (vegetables) & $\begin{array}{l}\text { Fleischwaren (meat } \\
\text { dishes) }\end{array}$ \\
\hline Kirsche (cherry) & Kuchen (pie) & Kaffee (coffee) & Karotte (carrot) & Kalbfleisch (veal) \\
\hline $\begin{array}{l}\text { Zuckermelone (mel- } \\
\text { on) }\end{array}$ & Zwieback (rusk) & $\begin{array}{l}\text { Zitronentee (tea with } \\
\text { lemon) }\end{array}$ & Zucchini (zucchini) & $\begin{array}{l}\text { Zungenwurst } \\
\text { (tongue sausage) }\end{array}$ \\
\hline Limette (lime) & $\begin{array}{l}\text { Lebkuchen (treacle } \\
\text { cake) }\end{array}$ & $\begin{array}{l}\text { Limonade (lemon- } \\
\text { ade) }\end{array}$ & Linse (lentil) & $\begin{array}{l}\text { Leberwurst (liver } \\
\text { sausage) }\end{array}$ \\
\hline
\end{tabular}

The tasks on the basis of the method "aspect-wordoutcome" can be worked out in accordance with the topics that are covered, for example, the topic "Im Warenhaus" (In the Department Store) (aspects of the topic: "Oberbekleidung" (Overcoats), "Wäsche" (Underwear), "Schuhe" (shoes), "Haushaltsartikel" (Household Goods), "Schreibwaren" (Stationery), etc.); topic "Das Wohnen" (Housing) (aspects of the topic: "Häuser und Wohnungen" (Houses and Apartments), "Einrichtung und Möbel" (Furniture), "Haushaltsmaschinen und Geräte" (Electric Appliances), etc.), topic "Die Freizeitgestaltung" (Leisure Time) (aspects of the topic: "Theater, Konzert" (theatre, concert), "Fernsehen" (Television), "Literatur" (Literature), "Musik, Tänze" (music, dances), "Sport" (Sport), "Gesellschaftsspiele" (Games and Plays), etc.).

Example 3. "Fishbowl Method" is a method of group discussion and all the students strictly keep to the place in the classroom where they are supposed to be.

Let us briefly outline the general idea of implementing the method:

1. Method application: holding a discussion on the certain topic; topic coverage; exchange of remarks, ideas and impressions after topic discussion.

2. Educational objectives: stimulation of cognitive processes; the development of personal and group responsibility; the development of persuasion skills and the ability to communicate one's own message; the development of the listening skills and the ability to quickly react to what has been previously mentioned.

3. Performance / method usage: 1. Using this method, it is important to keep to a certain space ordering in the classroom for all the participants of the group: the participants sit down together to make a small circle and one or two outer circles depending on the number of students; circling in a small group there are one or two moderators, the participants who actually start a discussion (one or two chairs are left vacant); the other participants are sitting in an outer circle. 2. The moderator announces the topic of discussion and explains the rules of holding it. 3. The participants who are in the small circle start sharing their ideas, trying to come up with their suggestions, persuade one another, present "for" and "against" arguments. 4. Those who are in the outer circle can enter the discussion if they have a new point to raise and they can only do it by occupying a vacant seat. They add new ideas and perspectives to the discussion. After having shared their opinions, they get back to the outer circle. 5. After the group discussion the participants sum up what has been said and report the results to their teacher or moderator.

4. Duration: the timing largely depends on the number of students participating in the discussion. Usually it takes 20-45 minutes.

5. Possible challenges in implementing the method/ ways of avoiding the challenges: among the possible challenges of implementing this method might be a breach of rules by the participants of the discussion. The way to prevent the problem is to pay attention to how the discussion goes and make sure the participants of the outer circle do not shout out, do not interrupt and do not hold too long discussions without giving a chance to other students to raise their concerns. This is the responsibility of either a teacher, or a moderator.

Example 4. "Sandwich Method" implies the comparison of students' results of work with the teacher's results. By doing this they learn to transform new information creatively and use it in the process of solving problems or simply doing a task. Let us briefly outline the general idea of implementing the method:

1. Method application: studying a new topic; systematizing and structuring the material covered; distributing large amount of information into manageable separate subtopics. 
2. Educational objectives: developing skills of analyzing new information and critically incorporating it into a working process; using the acquired knowledge and personal experience within a classroom setting.

3. Performance / method usage: 1. Announcing a topic or subtopic and the teacher's responsibilities; 2 . Dividing large groups into small ones (5 people max.), 3. Doing the tasks: step 1: working in small groups (1 phase): the members of the group write down their suggestions, critical remarks, and results of their work after discussing the topic and doing the task; step 2: a short summary from a teacher follows: the general topic is viewed in the context of informational blocks (objects, facts, experimental data, logical connections between the elements of the message, comparison of the text information with the subject, etc.); step 3: working in small groups ( 2 phase): the members of the group compare their results with the teacher's summary and improve, add, change the results of their own work (comparison with the teacher's summary $\rightarrow$ highlighting key ideas $\rightarrow$ creative transformation of the information received $\rightarrow$ adding, clarifying one's own work results $\rightarrow$ systematization of one's own work results); step 4: plenary session: the general presentation of the project work, information exchange, making conclusions with the account of new material integration into the existing framework.

4. Duration: 1. Working in small groups (1 phase): 15-30 minutes depending on the complexity of a topic. 2. A short summary from a teacher: approximately 15 minutes. 3. Working in small groups (2 phase): 20-30 minutes. 4. Work in plenary session: approximately 30 minutes or more.

5. Materials required: material for topic coverage (chosen by the members of the group); questions on flipchart, board, working sheets; presentation materials (chosen by the members of the group).

6. Possible challenges in implementing the method/ ways of avoiding the challenges: 1 . The participants have not understood the task. The way to prevent the problem is to announce the topic once more and clearly state the educational tasks which are visually presented on posters as instructions to the task. 2. During the first phase of the project the participants do their tasks and might be short of time to get ready with a written presentation of their work. The way to prevent the problem is to organize time properly. A teacher should also inform that students must follow the phases in the right way, because if the first task is not done the next tasks can hardly be performed. This motivates students and leads to their further successful coverage of the task.

Here is an example of "Sandwich Method" (topic "Motivation" (motivation, justification) while learning the German language):

Part 1. Working in small groups (not more than 5 people). Phase 1. Task: Diskutieren Sie: (answer the questions): "Wie sind Ihre persönlichen Einstellungen zum Lernen und zur Arbeit? Welche Motive leiten Sie?" (What is your personal attitude to work and studying?
What really motivates you?). Halten Sie die unterschiedlichen Motive schriftlich fest (put down your motivations on work sheets). Task time: 15 minutes.

Part 2. Teacher's report on two theories of motivations being visualized: Maslow's Hierarchy of Needs and Porter and Lawler Model of Motivation. Distributing handouts.

Part 3. Working in small groups. Phase 2. Task: Integrieren Sie das Gehörte in Ihre gemachten Aufzeichnungen und erarbeiten Sie in der Kleingruppe, wie Sie in Ihrem Betrieb Mitarbeiter motivieren können (integrate your own notes on what you discussed with new information from a teacher and work in small groups on the question "How would you motivate your colleagues in an ever-growing company”). Spüren Sie möglichen Chancen und Widerständen nach (discover all possible pros and cons). Bereiten Sie eine kurze Präsentation im Plenum vor, bestimmen sie Ihren Gruppensprecher (get ready with a short presentation, choose a speaker of your group). Task time: 30 minutes.

Part 4. Presentation of the results by speakers; discussing the learning outcomes.

Example 5. Station work, working at stations is about individual work of students on covering large amounts of topics which are distributed in the educational blocks. A teacher chooses adequate educational material based on every particular block that will later be studied by students individually or in small groups step by step. The students are encouraged to work on the material using various additional tools (dictionaries, Internet sources, etc.) that stipulate investigative and searching activity. Educational blocks are divided into mandatory and optional. In case the selective educational material has been opted, it is essential that students know and understand what blocks should be preferred in the context of their cognitive interests, intellectual and physical development, strengths and weaknesses in performance, readiness for responsible decision-making. It should be noted that within the station work students are working on the principle of getting into a quality (not quantity) of processing training material, choosing their own working pace and tasks sequence. The teacher acts as an observer, an adviser, a consultant who evaluates the learning process and a final result for the purpose of motivation and supporting students' success in achieving educational goals, preventing mistakes and overcoming educational barriers. It should be emphasized that in order to prevent chaos within this mode of work, it is important to outline transparent and understandable organizational rules and evaluation criteria of the final product of the training.

Let us provide an example of station work in the context of the topic "Character of a human being" ("Charakter des Menschen") (English/German) (see Fig. 2):

Exercise: Answer the question: What kind of person are you? Justify your opinion (Antworten Sie auf die Frage: Was für ein Mensch Sind Sie? Begründen Sie Ihre Meinung). 


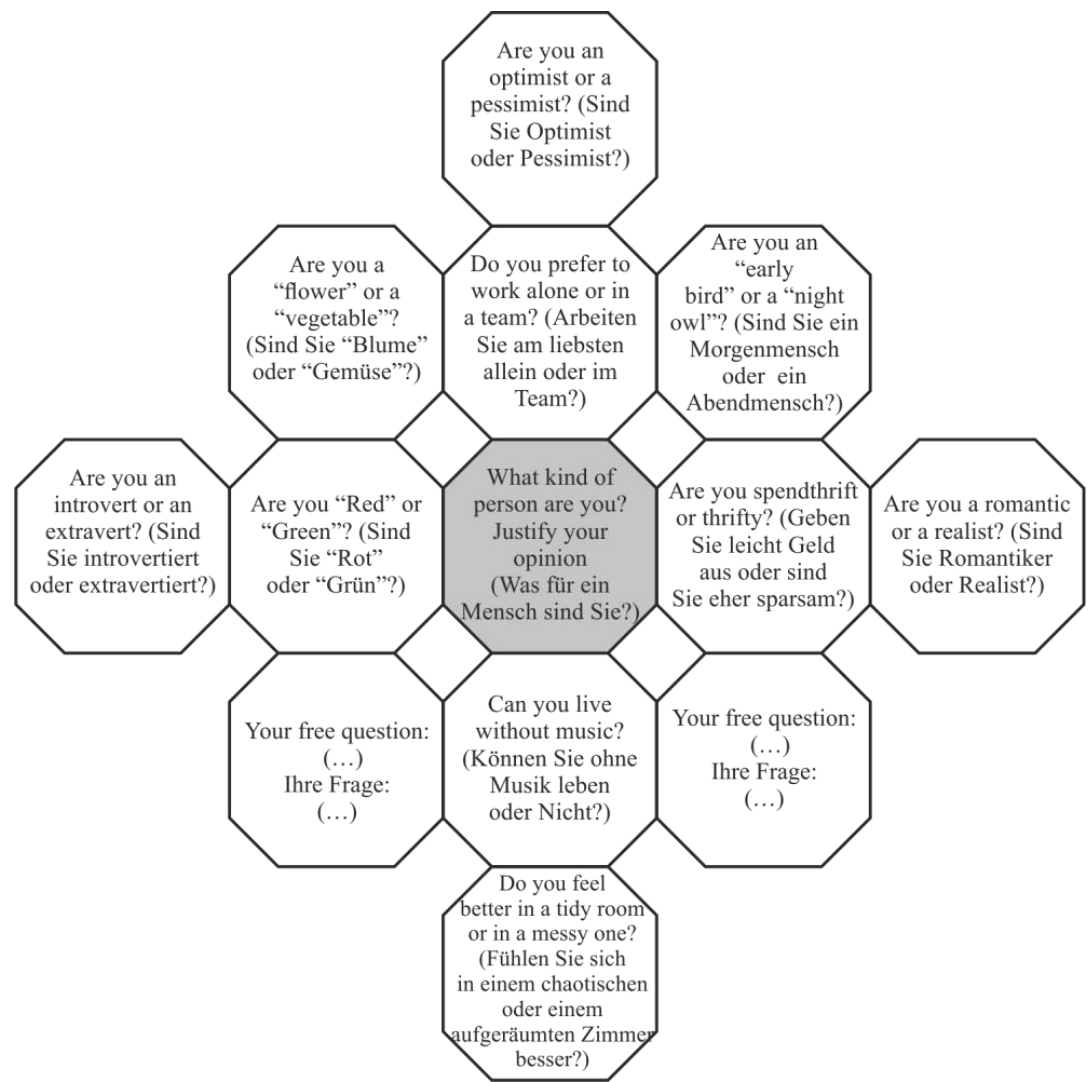

Fig. 2. Example of Station work

Example 6. The idea of the "Domino Method" implies the rules of the domino game. Students relate similar words or synonymic words in the framework of the material they cover. The peculiarities of this method are presented in the table:

1. Method application: revision of the material previously covered; using assessment for identifying the level of knowledge of the lexical material learnt.

2. Educational objectives: developing associative thinking and skills of logically and coherently relating synonymic words.

3. Performance / method usage: 1. Explaining the rules. 2. Dividing students into two or several groups (3-6 people in a group). 3. Every group receives a task previously prepared by a teacher in a format of "domino". 4 . In the center of the table "domino" cards are placed so that the words are at the bottom in the way students cannot see what is written on a card. 5. Every participant receives from 4 to 8 cards depending on the number of people in a group. They have to hold the cards so that other students do not see them. The other cards are on the table. 6. A teacher takes one of the cards and opens it to other students. The game starts. 7. The first participant chooses one of his/her cards that fits the word in the center and explains his/her choice. 8. The other students also choose from other cards those ones that match the words in the center and explain their choices. 9. If someone makes a mistake, his/her turn goes to another student. 10. If a student does not have a card that would be related to the words already displayed, he/she can take another card. In case that one does not fit either, he/she misses his/her turn. 11. The one who gets rid of all the cards first is the winner. 12. The game is over when all the cards are displayed in the right order. 13. The teacher observes how the students are performing the task. He/she corrects the possible errors. 14. Summarizing the game outcomes. Analyzing mistakes and errors.

4. Duration: approximately 20 minutes.

5. Possible challenges in implementing the method / ways of avoiding the challenges: 1 . Arguments about the group division. The way to prevent the problem is to make sure groups are divided fairly and openly. 2 . The content of the cards is unknown to students. The way to prevent the problem is to ensure that words and phrases are taken from the material covered and students know all of them.

Here is an example of "Domino Method" used in the process of learning English (selecting synonyms): 


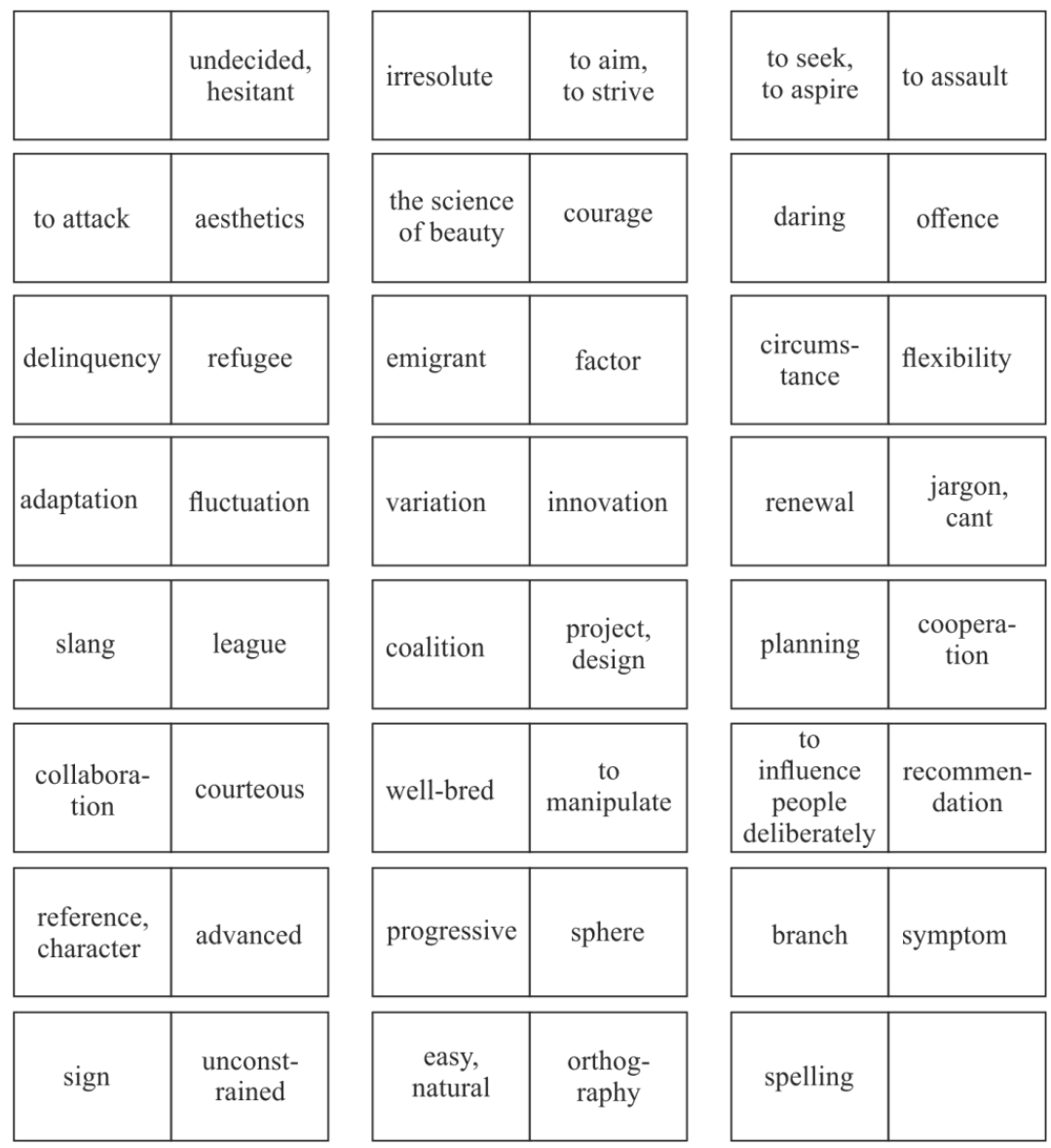

Fig. 3. Example of "Domino Plates" according to "Domino Method"

Outlining practical guidance on the application of the above mentioned training methods, we recommend teachers to observe teaching the principles of accessibility and consistency in increasing difficulties in the implementation of learning objectives and establish a system to use alternative methods and techniques of teaching foreign language communication in view of the interests, needs and motivations of students. It is important to take into consideration students' ability to boost their own selfesteem, relationships with communicators and psychological state. One should remember that using activityoriented teaching methods and techniques, students do not only learn to program their speech acts consciously, to define tasks related to the organization of verbal interaction with a partner within the subject or situation, but also evaluate the results of their own communication.

Also, in the context of non-traditional ways of the educational process, it is a student-centered approach that defines educational setting. The major role of a teacher is that of an observer, an advisor, a consultant who supports students and promotes their individual development. If a student faces an obstacle, in order to overcome it, there is a necessity of gradual productive work. It should be explained to students how to come to a decision on their own. It is important to encourage them to identify their own mistakes on the way to a final decision. They should learn how to process information needed for addressing errors, for example, to use dictionaries, textbooks, network products; to assist a school friend; to appeal to a teacher asking for an interview to select further learning strategy. If a student / a group of students makes a wrong decision in the process of solving a problem and does not move forward, the teacher may decide to hold consultative talks with a view of reconsideration of basic information. It is important to understand that the available forms of assistance (e.g. information, reference, formula, rules) should be depicted on posters at the time of consultation event in order to make everything clear and visualized. This is all done so that students learn to transform the available information skillfully with a view of a successful resolution of specific learning problems. The correctly planned curriculum promotes consultation mechanisms of self-understanding.

Unfortunately, within traditional practices of teaching and assessment, in which defects and learning problems of students lead to negative consequences, certain obstacles are safely hidden from a teacher as a person who controls in order to avoid negative interpretations and associations of weaknesses. In our opinion, it is proper methodologically conceived training advice from the teacher that directly affects the quality of learning outcomes. It promotes the creative potential of students, they develop skills for self-assessment and this will provide 
them with self-learning, and show the ability to learn throughout life.

An experiment at Ternopil V. Hnatiuk National Pedagogical University was carried out in order to check the efficiency of alternative methods used in FLT. It was run in three steps: diagnostic (which involved preliminary assessment), experimental study, and final assessment. The following statement served as a hypothesis for our experiment: "the FLT process will become more efficient provided learning is targeted and systematic in the process of doing special exercises focused on activity, which has a student as a subject of learning in its center, as much as it is aimed at revealing students' creative abilities". The experimental group involved 10 students studying German as a second foreign language. They were preliminary assessed in terms of their knowledge of grammatical and lexical minimum within the topic "Food". Before that the students did oral and written tasks of non-communicative type, concentrating on the form. For example, they asked questions to sentences, translated texts from German into Ukrainian, and vice versa, made complex sentences from simple ones, limited or extended them, changed or filled in with lexical units, did text retelling, learned new lexemes, sentences, texts, dialogues by heart, etc. The teacher used strict structuring of the study material, and made current assessment. Upon covering the topic preliminary assessment in the form of a test and its result allowed us to make the following conclusions:

1. The students' skills related to information request are not developed in a proper way. In particular, this concerns giving information (32\% of the students coped with this type of tasks); statements/opinions exchange ( $28 \%$ of the students coped with this type of tasks); mutual beliefs/grounding their point of view $(30 \%$ of the students coped with this type of tasks); writing a letter, abstract, making a plan on the topic $(35 \%$ of the students coped with this type of tasks).

2. The sudents have significantly better results in reproduction of the actual educational material (65\% of the students coped with the task).

In order to check the efficacy of tasks, designed on the basis of personality-centered and activity-based approach, experimental learning was organized and implemented in the experimental group in accordance with the theoretical and practical principles presented in this research. The students studied the topic "Character of a human being". They were offered methods and exercises promoting active search for various ways of solving study tasks and problem situations via revealing creative potential of a personality. Besides, the stress was also made on

\section{REFERENCES}

1. Bondar, S. P. (2012). Kompetentnisna spriamovanist zmistu i struktury navchalnoho predmeta $\mathrm{v}$ umovakh fundamentalizatsii osvity [Competency focus of the content and structure of a school subject in terms of fundamentalization of education]. Naukovyi chasopys NPU im. M.P. Drahomanova. Seriia 17. Teoriia i praktyka individual development of the students' cognitive abilities through stimulating the process of search and inventive activity. The teacher's role was no longer dominating. There was no strict structuring of the study material.

The final assessment test was made at the end of the experimental study. Its results allowed us to make the following conclusions:

1. The students have significantly improved skills and sub-skills related to information request. In particular, this concerns giving information $(85 \%$ of the students coped with this type of tasks comparing to $32 \%$ in the preliminary test); statements/opinions exchange $(80 \%$ of the students coped with this type of tasks comparing to $28 \%$ in the preliminary test); mutual beliefs/ grounding their point of view (83\% of the students coped with this type of tasks comparing to $30 \%$ in preliminary test); writing a letter, abstract, making a plan on the topic $(90 \%$ of the students coped with this type of tasks comparing to $35 \%$ in the preliminary test).

2. The students' results in pure reproduction have become considerably better ( $82 \%$ vs. $65 \%$ in a preliminary test).

Thus, the results of final assessment have proved the efficacy of using the suggested complex of exercises, focused on the activity, which has a student as a subject of learning in its center, and revealing students' creative abilities.

\section{Conclusions}

Our study materials give grounds to speak about the extraordinary significance of alternative methods of teaching foreign languages in the context of developing students' fundamental competencies, based on the principle of self-sufficient, conscious and effective life. It contributes to the further development of alternative (nontraditional) methods of teaching foreign language communication, which presupposed the idea personalitycentered and activity-oriented approach to teaching students who are responsible for their own intellectual and physical development, able to fulfil their potential, mental capabilities due to self-determination, self-affirmation and self-realization. The results of the experiment allowed us to make a conclusion that efficacy of competencyoriented foreign languages teaching depends on teacher's understanding of the necessity to abandon authoritarian and scholastic methods, and use the alternative teaching methods instead. Among the perspectives of further research studies we suggest revising and reconsidering the traditional methods and approaches in FLT at higher educational institutions.

navchannia ta vykhovannia - Scientific bulletin of National Dragomanov Pedagogical University. Theory and Practice of Education, 20, 10-23 [in Ukrainian].

2. Lokshyna, O. I. (2009). Stanovlennia kompetentnisnoi idei $\mathrm{v}$ yevropeiskii osviti [The CompetenceBased Idea Formation in the European Education]. Reali- 
zatsiia yevropeiskoho dosvidu kompetentnisnoho pidkhodu u vyshchii shkoli Ukrainy - Implementation of the European experience competence approach in higher education of Ukraine. Materialy metodolohichnoho seminaru - Proceedings of methodological seminar (pp. 1933). Kyiv: Pedahohichna dumka [in Ukrainian].

3. Rodyhina, I. V. (2008). Kompetentnisno oriientovanyi pidkhid do navchannia [Competencyoriented approach to learning]. Kharkiv: Vydavnycha hrupa «Osnova» [in Ukrainian].

4. Savchenko, O. Ya. (2011). Kompetentnisnyi pidkhid yak chynnyk modernizatsii zmistu osvity [The Competence-Based Approach as a Factor of the Educational Contents Modernization]. Nauka i osvita. Naukovopraktychnyi zhurnal Pivdennoho naukovogo tsentru Ukrainy - Science and Education. Scientific journal of Southern scientific centre of Ukraine, 4, 13-17 [in Ukrainian].

5. Soshenko, S. M. \& Kolomiiets, B. S. (2014). Evoliutsiia metodiv vykladannia inozemnoi movy [Evolution of methods of FLT]. Pedahohichnyi protses: teoriia $i$ praktyka - Pedagogical process: theory and practice, 1 , 22-27. Retrieved from : http://nbuv.gov.ua/UJRN/pptp [in Ukrainian].

6. Trubacheva, S. E. (2004). Umovy realizatsii kompetentnisnoho pidkhodu $\mathrm{v}$ navchalnomu protsesi [Conditions for implementation of competency-based approach into educational process]. Kompetentnisnyi pidkhid u suchasnii osviti: svitovyi dosvid ta ukrainski perspektyvy - Competency-based approach in modern education: world experience and Ukrainian perspectives. O. V. Ovcharuk (Ed.). Kyiv: K.I.C [in Ukrainian]

7. Ende, K., Grotjahn, R., Kleppin, K. \& Mohr, I. (2013). Curriculare Vorgaben und Unterrichtsplanung

\section{ЛІТЕРАТУРА}

1. Бондар С. П. Компетентнісна спрямованість змісту і структури навчального предмета в умовах фундаменталізації освіти / С. П. Бондар // Науковий часопис НПУ ім. М.П. Драгоманова. Серія 17. Теорія і практика навчання та виховання. - К. : Вид-во НПУ ім. М.П. Драгоманова, 2012. - Вип. 20. - С. 10-23.

2. Локшина О. І. Становлення компетентнісної ідеї в європейській освіті / О. І. Локшина // Реалізація європейського досвіду компетентнісного підходу у вищій школі України. Матеріали методологічного семінару. - К. : Педагогічна думка, 2009. - С. 19-33.

3. Родигіна I. В. Компетентнісно орієнтований підхід до навчання / I. В. Родигіна. - Х. : Вид. група «Основа», 2008. - 112 с.

4. Савченко О. Я. Компетентнісний підхід як чинник модернізації змісту освіти / О. Я. Савченко // Наука і освіта. Науково-практичний журнал Південного наукового центру НАПН України. Серія «Педагогіка». - 2011. - № 4. - С. 13-17.

5. Сошенко С. М. Еволюція методів викладання іноземної мови / С. М. Сошенко, Б. С. Коломієць // Педагогічний процес: теорія і практика. - 2014. - Вип.
[Curriculum and lesson planning]. München : KlettLangenscheidt [in German].

8. Bausch, K.-R., Christ, H. \& Krumm, H.-J. (1995). Fremdsprachenunterricht [A foreign language lesson]. Tübingen : Francke Verlag Tübingen und Basel [in German].

9. Hugenschmidt, B. \& Technau, A. (2011). Methoden schnell zur Hand. 66 Schüler- und handlungsorientierte Unterrichtsmethoden [Textbook on methods. 66 individually and activity-oriented methods of teaching]. Leipzig : Klett, Kallmeyer [in German].

10. Kramsch, C. (2014). The Challenge of Globalization for the Teaching of Foreign Languages and Cultures. Electronic Journal of Foreign Language Teaching, 11 (2), 249-254. Retrieved from: http:///eflt.nus.edu.sg/v11n22014/kramsch.pdf [in English].

11. Mattes, W. (2012). Methoden für den Unterricht [Methods of teaching]. Braunschweig, Paderborn, Darmstadt : Schöningh Verlag [in German].

12. Widodo, H. P., Budi, A. B. \& Wijayanti, F. (2016). Poetry Writing 2.0: Learning to Write Creatively in a Blended language Learning Environment. Electronic Journal of Foreign Language Teaching, 13 (1), 30-48. Retrieved from: http://eflt.nus.edu.sg/v13n12016/widodo.pdf [in English].

13. Schuetze, U. \& Lowey, E. (2015). Learning the Subjunctive in German: With or Without Technology? Electronic Journal of Foreign Language Teaching, 12 (1), 69-78. Retrieved from: http://eflt.nus.edu.sg/v12n12015/schuetze.pdf [in English].

14. Ballweg, S., Drumm, S., Hufeisen, B., Klippel, J. \& Pilypaityte, L. (2013). Wie lernt man die Fremdsprache Deutsch? [How is German as a foreign language studied?]. München : Klett-Langenscheidt [in German].

1. - С. 22-27. - Режим доступу: http://nbuv.gov.ua/UJRN/pptp

6. Трубачева С. Е. Умови реалізації компетентнісного підходу в навчальному процесі / С. Е. Трубачева // Компетентнісний підхід у сучасній освіті: світовий досвід та українські перспективи: під заг. ред. О. В. Овчарук. - К. : К.І.С., 2004. - С. 51-57.

7. Curriculare Vorgaben und Unterrichtsplanung / K. Ende, R. Grotjahn, K. Kleppin, I. Mohr-. - München : Klett-Langenscheidt, 2013. - 152 S.

8. Fremdsprachenunterricht / K.-R. Bausch, H. Christ, H.-J. Krumm. - Tübingen : Francke Verlag Tübingen und Basel, 1995. - $585 \mathrm{~S}$.

9. Hugenschmidt B. Methoden schnell zur Hand. 66 Schüler- und handlungsorientierte Unterrichtsmethoden / B. Hugenschmidt, A. Technau. - Leipzig : Klett, Kallmeyer, 2011. $-213 \mathrm{~s}$.

10. Kramsch $\mathrm{C}$. The Challenge of Globalization for the Teaching of Foreign Languages and Cultures [Електронний ресурс] / C. Kramsch // Electronic Journal of Foreign Language Teaching. - 2014, Vol. 11. No. 2, pp. 
249-254. - Режим доступу: http:///eflt.nus.edu.sg/v11n22014/kramsch.pdf

11. Mattes W. Methoden für den Unterricht / W. Mattes. - Braunschweig, Paderborn, Darmstadt : Schöningh Verlag, 2012. - $132 \mathrm{~s}$.

12. Poetry Writing 2.0: Learning to Write Creatively in a Blended language Learning Environment [Електронний ресурс] / H.P. Widodo, A. B. Budi, F. Wijayanti // Electronic Journal of Foreign Language Teaching. 2016, Vol. 13. No. 1, pp. 30-48. - Режим доступу: http://e-flt.nus.edu.sg/v13n12016/widodo.pdf
13. Schuetze U. Learning the Subjunctive in German: With or Without Technology? [Електронний pecypc] / U. Schuetze, E. Lowey // Electronic Journal of Foreign Language Teaching. - 2015, Vol. 12. No. 1, pp. 69-78. - Режим доступу: http://eflt.nus.edu.sg/v12n12015/schuetze.pdf

14. Wie lernt man die Fremdsprache Deutsch? / S. Ballweg, S. Drumm, B. Hufeisen, J. Klippel, L. Pilypaityte. - München : Klett-Langenscheidt, 2013. - 108 S

Інна Василівна Шимків, кандидат педагогічних наук, доиент кафедри німецької філологї та методики викладання німецької мови,

Анатолій Олегович Клименко,

кандидат педагогічних наук, дочент кафедри практики англійської мови та методики ї̈ викладання,

Наталія Іванівна Закордонець, кандидат педагогічних наук, дочент кафедри іноземних мов, Тернопільський національний педагогічний університет ім. Володимира Гнатюка, вул. М. Кривоноса, 2, м. Тернопіль, Украӥна

\section{РЕАЛІЗАЦІЯ АЛЬТЕРНАТИВНИХ МЕТОДІВ НАВЧАННЯ ІНОЗЕМНИХ МОВ В СВІТЛІ КОМПЕТЕНТНІСНОГО ПІДХОДУ}

Методика навчання іноземних мов зазнає значних змін, перебуваючи у пошуку найбільш прийнятних для сьогодення раціональних підходів. Новий етап у розвитку іншомовної освіти пов'язаний, насамперед, 3 упровадженням компетентнісного підходу до організації навчального процесу і формування інноваційної людини, яка може гнучко пристосуватись до світових соціально-політичних і економічних факторів. Актуальне питання компетентнісно-спрямованого навчання досліджується в сучасних працях науковців, але окремі аспекти згаданої проблеми залишаються малодослідженими. Метою статті є висвітлення основних підходів альтернативних методів навчання іноземних мов у контексті компетентнісного підходу. Дослідження проводилося 3 використанням таких методів, як критичний аналіз методичної літератури, синтез, порівняння, узагальнення, а також емпіричні методи: спостереження, тестування, узагальнення практичного досвіду вчителів, педагогічний експеримент. Увага у дослідженні сфокусована на осмисленні продуктивних тенденцій організації навчання іноземних мов у контексті індивідуально та діяльнісно орієнтованих технологій, які пов'язують 3 альтернативними методами навчання в контексті компетентнісного підходу, що дають учням можливість самостійно досліджувати проблеми, спостерігати, аналізувати, критично мислити, організовувати свої власні прийоми навчання, відстоювати власну позицію, розвивати вміння оцінювати ризики, формувати конструктивне управління почуттями, застосовувати інформаційно-комунікаційні технології, взаємодіяти в адекватний і творчий спосіб у всіх різновидах соціальних та культурних контекстів, мобілізовувати життєвий досвід, застосовувати базові / декларативні знання та уміння на практиці, створювати ситуації успіху, використовувати самоконтроль та взаємоконтроль. Результати проведеного експерименту дозволили зробити висновок про те, що ефективність компетентнісно спрямованого навчання іноземних мов залежить від розуміння викладачами необхідності відмовитися від авторитарних і схоластичних методів та творчо застосовувати методи, що сприяють розвитку та самовдосконаленню навчально-комунікативного процесу.

Ключові слова: альтернативні методи навчання, компетентнісний підхід, особистісно зорієнтоване навчання, діяльнісно зорієнтовані технології навчання, оцінювання, мотивація, самоконтроль, навчальна консультація.

Submitted on April, 17, 2017

Reviewed by Doctor of Pedagogy, prof. L. Morska 